\title{
Whole blood lead levels are associated with biomarkers of joint tissue metabolism in African American and White men and women: The Johnston County Osteoarthritis Project
}

\author{
Amanda E. Nelson ${ }^{a}$, Sanjay Chaudhary ${ }^{a}$, Virginia B. Kraus ${ }^{b}$, Fang Fang ${ }^{\mathrm{C}}$, Jiu-Chiuan \\ Chen ${ }^{d}$, Todd A. Schwartz ${ }^{a, e}$, Xiaoyan A. Shi ${ }^{f}$, Jordan B. Renner ${ }^{a, g}$, Thomas V. Stabler ${ }^{b}$, \\ Charles G. Helmick $^{h}$, Kathleen Caldwell ${ }^{h}$, A. Robin Poole ${ }^{i}$, and Joanne M. Jordan ${ }^{a}$ \\ aThurston Arthritis Research Center, University of North Carolina, 3300 Thurston Bldg, Chapel \\ Hill, NC, 27599, USA \\ bDuke University Medical Center, 595 La Salle St., Durham, NC, 27710, USA \\ 'StatWorks, Inc, 79 T.W. Alexander Drive, RTP, NC, 27709, USA \\ dUniversity of Southern California, Department of Preventative Medicine, Division of \\ Environmental Health, 1540 Alcazar St., Los Angeles, CA, 90089, USA \\ eDepartment of Biostatistics, Gillings School of Global Public Health, University of North Carolina, \\ 3106E McGavran-Greenberg Hall, Chapel Hill, NC, 27599, USA \\ fSAS Institute, Inc, SAS Campus Drive, Cary, NC, 27513, USA \\ gUniversity of North Carolina, Department of Radiology, 509 Old Infirmary BIdg, Chapel Hill, NC, \\ 27599, USA \\ ${ }^{h}$ Centers for Disease Control and Prevention, 1600 Clifton Rd, Atlanta, GA, 30333, USA \\ iJoint Diseases Laboratory, Shriners Hospital; Department of Surgery, McGill University, 1529 \\ Cedar Ave, Montreal, Quebec, H3G 1A6, Canada
}

\section{Abstract}

Purpose-To examine associations between biomarkers of joint tissue metabolism and whole blood lead $(\mathrm{Pb})$, separately for men and women in an African American and Caucasian population, which may reflect an underlying pathology.

Methods-Participants in the Johnston County Osteoarthritis Project Metals Exposure Sub-study (329 men and 342 women) underwent assessment of whole blood $\mathrm{Pb}$ and biochemical biomarkers of joint tissue metabolism. Urinary cross-linked N telopeptide of type I collagen (UNTX-I) and C-

\footnotetext{
(C) 2011 Elsevier Inc. All rights reserved.

Corresponding Author: Amanda E. Nelson, MD MSCR, University of North Carolina at Chapel Hill, Thurston Arthritis Research Center, 3300 Thurston Building, CB \# 7280, Chapel Hill, NC 27599-7280, aenelson@ med.unc.edu, Phone: 919-966-0553; Fax: 919-966-1739.

Publisher's Disclaimer: This is a PDF file of an unedited manuscript that has been accepted for publication. As a service to our customers we are providing this early version of the manuscript. The manuscript will undergo copyediting, typesetting, and review of the resulting proof before it is published in its final citable form. Please note that during the production process errors may be discovered which could affect the content, and all legal disclaimers that apply to the journal pertain.

Disclosure statement: Dr. A. Robin Poole is a consultant to Ibex Pharmaceuticals. Otherwise, the authors have no conflicts to report. The findings and conclusions in this report are those of the authors and do not necessarily represent the official position of the Centers for Disease Control and Prevention.

As noted on page 5, "This study has been approved by the Institutional Review Boards of the Centers for Disease Control and Prevention and the University of North Carolina."
} 
telopeptide fragments of type II collagen (uCTX-II), and serum cleavage neoepitope of type II collagen $(\mathrm{C} 2 \mathrm{C})$, serum type II procollagen synthesis C-propeptide (CPII), and serum hyaluronic acid (HA) were measured using commercially available kits; the ratio of [C2C:CPII] was calculated. Serum cartilage oligomeric matrix protein (COMP) was measured by an in-house assay. Multiple linear regression models were used to examine associations between continuous blood $\mathrm{Pb}$ and biomarker outcomes, adjusted for age, race, current smoking status, and body mass index. Results are reported as estimated change in biomarker level for a 5-unit change in Pb level.

Results-The median $\mathrm{Pb}$ level among men and women was 2.2 and $1.9 \mu \mathrm{g} / \mathrm{dL}$, respectively. Correlations were noted between Pb levels and the biomarkers uNTX-I, uCTX-II, and COMP in women, and between $\mathrm{Pb}$ and $\mathrm{UCTX}$-II, COMP, CPII, and the ratio [C2C:CPII] in men. In adjusted models among women, a 5-unit increase in blood $\mathrm{Pb}$ level was associated with a $28 \%$ increase in uCTX-II and a 45\% increase in uNTX-I levels (uCTX-II: 1.28 [95\%CI: 1.04-1.58], uNTX-I: 1.45 [95\% CI:1.21-1.74]). Among men, levels of $\mathrm{Pb}$ and COMP showed a borderline positive association (8\% increase in COMP for a 5-unit change in Pb: 1.08 [95\% CI: 1.00-1.18])); no other associations were significant after adjustment.

Conclusions-Based upon known biomarker origins, the novel associations between blood $\mathrm{Pb}$ and biomarkers appear to be primarily reflective of relationships to bone and calcified cartilage turnover among women and cartilage metabolism among men, suggesting a potential genderspecific effect of $\mathrm{Pb}$ on joint tissue metabolism that may be relevant to osteoarthritis.

\section{Keywords}

Biomarkers; blood lead; joints; osteoarthritis

\section{Introduction}

Approximately $95 \%$ of total body lead $(\mathrm{Pb})$ burden in adults is stored in bone (Wittmers, Jr. et al. 1988), and despite decreased $\mathrm{Pb}$ exposure in the United States in recent years (Muntner et al. 2005; Centers for Disease Control and Prevention (CDC) 2009), people with previous exposure to this ubiquitous environmental toxicant may have accumulated significant $\mathrm{Pb}$ burden in bone. Bone $\mathrm{Pb}$ has a half-life of decades, and contributes as much as $65 \%$ to measured whole blood $\mathrm{Pb}$ levels (Barry and Mossman 1970). The stored bone $\mathrm{Pb}$ can be released into blood chronically, especially during times of increased bone turnover (Machida et al. 2009; Nie et al. 2009), making bone both a potential target tissue for Pb toxicity and a persistent endogenous source of $\mathrm{Pb}$ (Symanski and Hertz-Picciotto 1995;Mushak 1993; Osterloh et al. 1994;Berlin et al. 1995; Nash et al. 2004). Even mild elevations in blood $\mathrm{Pb}$ may have health consequences, including increased mortality, as shown by recent studies using data from the Third National Health and Nutrition Examination Survey (Schober et al. 2006) and the Study of Osteoporotic Fractures (Khalil et al. 2009).

There exist several biologically plausible ways by which long-term exposure to $\mathrm{Pb}$ may impact bone and other joint structures in humans. For instance, $\mathrm{Pb}$ is known to interfere with dietary calcium uptake and metabolism, conversion of vitamin $\mathrm{D}$ to $1,25-\mathrm{OH}$ vitamin $\mathrm{D}$, and other regulatory aspects of bone cellular function and matrix and osteocalcin synthesis (Berlin et al. 1995; Fullmer 1997; Pounds et al. 1991). Pb exposure leads to impaired collagen synthesis by osteoblasts and impaired resorptive capacity by osteoclasts (Pounds et al. 1991). Aside from its effects on bone, recent data suggest effects of $\mathrm{Pb}$ on cartilage and chondrocytes as well. Zuscik and colleagues reported reversion of articular chondrocytes to a more primitive phenotype upon $\mathrm{Pb}$ exposure, with matrix degradation and mineralization, decreased TGF- $\beta$ signaling, and chondrocyte hypertrophy (Zuscik et al. 2006). A related study revealed impairments in fracture healing in $\mathrm{Pb}$-exposed mice, with associated delays in endochondral maturation (Carmouche et al. 2005). In a study of bone samples from 
individuals without known bone disease or $\mathrm{Pb}$ exposure, Zoeger and colleagues identified marked differential accumulation of $\mathrm{Pb}$ in the cartilage tidemark, the transition between calcified and non-calcified cartilaginous $m$ atrix (Zoeger et al. 2006), where clefts occur as osteoarthritis develops. The affinity of $\mathrm{Pb}$ for joint tissues, and the role of $\mathrm{Pb}$ in cartilage and bone maturation and repair shown in the above studies, suggest a potential role for $\mathrm{Pb}$ in the osteoarthritis disease process, which affects bone, cartilage, and notably the tidemark area of cartilaginous matrix.

Associations between blood and bone $\mathrm{Pb}$ and bone biomarkers have been identified (Tsaih et al. 2001;Machida et al. 2009;Dowd et al. 2001), but there have been no studies assessing potential associations between whole blood $\mathrm{Pb}$ levels and biomarkers of joint metabolism. We examined a panel of serum and urine biomarkers, as quantitative indicators of bone and cartilage turnover (urinary cross-linked N telopeptide of type I collagen (UNTX-I), urinary C-telopeptide fragments of type II collagen (uCTX-II), serum cartilage oligomeric matrix protein (COMP), serum cleavage neoepitope of type II collagen (C2C), serum type II procollagen synthesis $\mathrm{C}$-propeptide (CPII), the ratio of [C2C:CPII], and hyaluronic acid (HA)), in relationship to whole blood $\mathrm{Pb}$ among participants in the Johnston County Osteoarthritis Project. We hypothesized that $\mathrm{Pb}$ levels may be associated with both skeletal and other joint tissue metabolism, as reflected by levels of these biomarkers, which may be of potential relevance to osteoarthritis.

\section{Patients and Methods}

\subsection{Study Population}

The Johnston County Osteoarthritis Project is a population-based study in which civilian, non-institutionalized African American and White individuals, 45 years of age and older, were recruited from 1991-7 by probability sampling of six townships in Johnston County as previously described (Jordan et al. 2007). The Metals Exposure Sub-study, including whole blood $\mathrm{Pb}$ assessment, was designed to consist of 1700 consecutive individuals either newly enrolled in 2003-4, or returning for follow-up in 2006-8. The sample for the current analysis includes individuals who had complete blood $\mathrm{Pb}$ data when the biomarker assays were performed, consisting of 342 women and 212 men enrolled in 2003-4, and 117 men returning for follow-up in 2006-8. The characteristics of this subsample were similar to those of the overall metals sample $(n=1635$, Table 1$)$. This study has been approved by the Institutional Review Boards of the Centers for Disease Control and Prevention and the University of North Carolina.

Demographic and clinical information was obtained by interview, race was self-reported, and current smoking status was assessed by questionnaire, coded as either a current smoker or a current nonsmoker. Participants underwent a clinical evaluation, which included measurement of height $(\mathrm{m})$ without shoes and weight $(\mathrm{kg})$ measured with a balance beam scale, followed by calculation of body mass index (BMI, in $\mathrm{kg} / \mathrm{m}^{2}$ ). For women, menopausal status was determined by an affirmative answer to the following question: "Have you reached menopause or change of life?" For those who were not sure how to answer this question, post-menopausal status was inferred by the absence of menstrual periods for 2 years in women aged 50 and older, or by the report of surgical removal of both ovaries. Female participants were also asked if they were currently using, or had ever used hormone pills, creams, patches, or shots, not including birth control pills. These factors were included in adjusted analyses due to known effects of race, smoking, and menopausal status on biomarker and blood $\mathrm{Pb}$ levels. 


\subsection{Blood Lead (Pb) Assay}

Whole blood was collected utilizing certified metal-free blood drawing equipment and vials, and stored at $\sim 4$ degrees (Wang and Peter 1985;Subramanian 1995) until shipment in batches of 50-100 to the Division of Laboratory Sciences (National Center for Environmental Health, Centers for Disease Control and Prevention, CDC) for analysis. Whole blood $\mathrm{Pb}$ concentrations were determined at the $\mathrm{CDC}$ using the PerkinElmer Inductively coupled plasma-dynamic reaction cell-mass spectrometer 6100 ELAN series DRC II, ELAN® DRC II ICP-MS (PerkinElmer SCIEX, Concord, Ontario, Canada) equipped with a Meinhard nebulizer and cyclonic spray chamber. In this multi-element analytical technique, blood samples are diluted with $\geq 18 \mathrm{M}$-ohm.cm water and with diluent containing $1 \% \mathrm{v} / \mathrm{v}$ tetramethyl-ammonium hydroxide, $0.5 \%$ disodium ethylenediamine tetraacetate, $10 \%$ ethyl alcohol, and $0.05 \%$ Triton X-100. Gold is added to reduce intrinsic mercury memory effects. Bismuth was added for the internal standardization of $\mathrm{Pb}$. The samples were prepared with the following ratio: (Sample: Water: Diluent $=1: 1: 48) . \mathrm{Pb}$ was quantified based on the ratio of analyte signal to that of the internal standard signal in peak hopping mode. The calibration was external matrix matched, control samples were assessed along with participant samples, and accuracy was verified by the analysis of standard reference material (SRM 955 c) from the National Institute of Standards Technology. For Pb the limits of detection in $\mu \mathrm{g} / \mathrm{dL}$ was based upon the standardization of base blood material and was $0.25 \mu \mathrm{g} / \mathrm{dL}(\mathrm{n}=284)$. The inter-assay precisions (relative standard deviations) for lead was $3.2 \%$ at a level of $2.89 \mu \mathrm{g} / \mathrm{dL}$.

\subsection{Bone and joint tissue biomarker assays}

Blood samples for serum biomarker determination were collected, spun and separated on site, and stored at $-86^{\circ} \mathrm{C}$. Second morning void urine samples were collected, spun and stored at $-86^{\circ} \mathrm{C}$ within 8 hours of processing. Details of individual marker properties and assays are as follows:

Urine NTX-I (cross linked N telopeptide of type I collagen) is a marker of bone resorption/turnover in health and is increased in osteoporosis (Scariano et al. 1998) and in osteoarthritis (Bettica et al. 2002). Urine NTX-I was measured using the commercially available Osteomark NTX Urine kit (Wampole Laboratories, Princeton, $\mathrm{NJ}$ ), a competitive-inhibition enzyme linked immunosorbent assay (ELISA) with reported precision of between 5-19\% intra-assay and 3-5\% inter-assay variability. Results are corrected for urine creatinine concentration with final values reported as $\mathrm{nM}$ $\mathrm{BCE} / \mathrm{mM}$ creatinine.

Urine CTX-II (urinary C-telopeptide fragments of type II collagen) is associated with both the prevalence and the progression of radiographic knee and hip osteoarthritis, independent of known clinical risk factors for osteoarthritis (Christgau et al. 2001;Reijman et al. 2004;Kong et al. 2006;Meulenbelt et al. 2006), and is related to bone, cartilage, and prominently to calcified cartilage turnover (Tomiya et al. 2008;BayJensen et al. 2008). This marker was measured using the commercially available Urine Cartilaps competitive ELISA (Nordic Bioscience, Herlev, Denmark), which has a reported precision of between 4.6-7.8\% intra-assay and 6.9-12.2\% inter3 assay variability. Results are corrected for urine creatinine concentration and final values reported as ng CTX-II /mM creatinine.

Serum COMP (cartilage oligomeric matrix protein), a non-collagenous matrix protein found in cartilage, meniscus, tendon, and ligament (Garnero et al. 2000;Petersson et al. 1998), is a widely studied and validated cartilage biomarker in relation to osteoarthritis (Clark et al. 1999; Jordan et al. 2003; Sharif et al. 1995b). COMP was measured using a previously described sandwich ELISA method utilizing monoclonal antibodies $16 \mathrm{~F} 12$ 
and $17 \mathrm{C} 10$, with a precision of between $5.8-6.6 \%$ intra-assay and $8.7-9.7 \%$ inter-assay variability (Vilim V et al. 2002). Results are reported as ng/ml COMP.

Serum C2C (collagenase-generated cleavage neoepitope of type II collagen) is indicative of cartilage collagen degradation, and is elevated in animal models of osteoarthritis (Chu et al. 2002; Matyas et al. 2004). Elevation of urine C2C (but not serum) is associated with pre-radiographic knee osteoarthritis onset (Cibere et al. 2009); in this study only serum $\mathrm{C} 2 \mathrm{C}$ was measured, using the commercially available Collagen Type II Cleavage ELISA (Ibex Pharmaceuticals, Montreal, Quebec, Canada). This competitive ELISA has a reported precision of 9.7\% intra-assay (Mazzuca et al. 2006) and $<20 \%$ inter-assay variability (Ibex data sheet). Results are reported as $\mathrm{ng} / \mathrm{ml} \mathrm{C2C}$.

Serum CPII (type II collagen c-propeptide) is cleaved from type II procollagen following release of synthesized procollagen in cartilage matrix, and is therefore indicative of type II collagen synthesis (Nelson et al. 1998); CPII was measured using the commercially available Procollagen II C-Propeptide ELISA (Ibex Pharmaceuticals, Montreal, Quebec, Canada). This competitive ELISA has a reported precision of 6.4\% intra-assay (Mazzuca et al. 2006) and <25\% inter-assay variability (Ibex data sheet). Results are reported as $\mathrm{ng} / \mathrm{ml}$ CPII.

Serum [C2C:CPII] ratio was calculated from the values of serum C2C and CPII. This ratio is indicator of the balance between cartilage collagen degradation and synthesis which is reflective progression of knee osteoarthritis (Cahue et al. 2007).

Serum HA (hyaluronan), a widely distributed large polysaccharide, is usually regarded as an indicator of synovial inflammation in arthritis (Wells et al. 1992;Georges et al. 1997; Sharif et al. 1995a), and may be associated with total osteoarthritis burden (Kraus VB et al. 2009). We and others have reported strong and robust associations between both serum COMP and serum HA levels and the presence and severity of radiographic osteoarthritis (Clark et al. 1999; Sharif et al. 1995b). It was measured using the commercially available Hyaluronic Acid Test kit (Corgenix, Westminster, CO), an enzyme-linked binding protein assay with a reported precision of between $3.6-4.7 \%$ intra-assay and 5.7-7.0\% inter-assay variability. Results are reported in ng/ml HA.

Urine Creatinine was measured using the commercially available Metra Creatinine Assay kit (Quidel, San Diego, CA), a colorimetric assay based on a modified Jaffe method with a reported precision of between $1.1-2.1 \%$ intra-assay and $2.0-6.9 \%$ inter-assay variability. Results were used to correct the urine measures (uCTX-II and uNTX-I).

\subsection{Statistical Analysis}

A total of 329 men and 342 women had available data for whole blood $\mathrm{Pb}$ and serum and urine biomarker (uNTX-I, uCTX-II, COMP, C2C, CPII, [C2C:CPII], and HA) analyses. Due to known gender differences in biomarkers of joint metabolism (Jordan et al. 2003;Kojima et al. 2008;Elliot et al. 2005; Mouritzen al. 2003), previously shown variations in $\mathrm{Pb}$ level by gender, and our a priori hypotheses, all results were stratified by gender. Natural logarithm transformation was used to produce distributions closer to normality for the biomarkers in these analyses. Descriptive statistics were calculated for demographic variables, smoking status, BMI, blood $\mathrm{Pb}$, and the biomarkers. Spearman correlation coefficients and 95\% CIs were computed between $\mathrm{Pb}$ and each biomarker. Due to known effects of race and smoking both $\mathrm{Pb}$ and biomarker levels, the differences in mean $\mathrm{Pb}$ (lntransformed $\mathrm{f}$ or $\mathrm{t}$-tests) and biomarkers by race and smoking status were tested by separate two sample Student's t-tests.

Separate multiple linear regression models were used to examine the associations between $\mathrm{Pb}$ and the natural log of each of the biomarkers: uNTX-I, uCTX-II, COMP, C2C, CPII, 
[C2C:CPII], and HA. The models were adjusted for variables known to impact blood $\mathrm{Pb}$ and/or biomarker levels: categorical race and smoking status, and continuous age and BMI. All of these covariates affected the estimates and were included in final models. Among women only, additional analyses were conducted restricted to only post-menopausal women and further adjusted for current hormone replacement therapy. The results of these models are presented as the estimated change in biomarker level for each 5-unit change in continuous blood $\mathrm{Pb}$ level.

A full model for each biomarker included two-way interactions between $\mathrm{Pb}$ and each of age, $\mathrm{BMI}$, race, and smoking, as well as polynomials of $\mathrm{Pb}$ up to the cubic power. Backward selection was conducted to remove one interaction or the highest order polynomial term at a time until all $\mathrm{p}<0.1$. A $\mathrm{p}$-value $<0.1$ for an interaction term was considered noteworthy for potential effect modification, and supplemental analyses including the interaction term were performed as needed.

Sensitivity analyses were performed by inclusion and exclusion of the outlying observations, which were defined as those with studentized residuals $>3$ (Kutner $M$ et al. 2004). One high value and one low value of COMP were excluded from the analysis of COMP among women, as the results were found to be sensitive to these two outlying values. No other biomarker analyses were sensitive to outliers (results did not change when the values were excluded), so all of the available observations were included in the remainder of the analyses.

\section{Results}

\subsection{Women}

There were 342 women with data for biomarkers and whole blood $\mathrm{Pb}$; of these, one was missing menopausal status, two were missing HRT use status, 3 were missing serum samples, and 12 did not have available urine samples. This left 330 women for analyses of urine biomarkers and 339 women for serum biomarkers. Demographic and clinical characteristics are shown in Table 1. Participants had a mean age of 62 years, slightly over one-third of women were African American, $18 \%$ were current smokers, and about 1/3 had radiographic knee osteoarthritis. The mean BMI among these women was about $31 \mathrm{~kg} / \mathrm{m}^{2}$. The vast majority (96\%) were post-menopausal, with $18 \%$ of those reporting current HRT usage. The median and range values for whole blood $\mathrm{Pb}$ and biomarkers are shown in Table 2 .

The median $\mathrm{Pb}$ level was $1.9 \mu \mathrm{g} / \mathrm{dL}$ (range from 0.5-25.4 $\mu \mathrm{g} / \mathrm{dL}$ ). The mean $\mathrm{Pb}$ level (lntransformed for t-tests) was noted to be higher among African American compared to Caucasian women, as were mean levels of $\ln$ uCTX-II, ln COMP, and ln C2C. Unadjusted analyses showed significant correlations between Pb and uNTX-I, uCTX-II, and COMP, but not with any of the other biomarkers (Table 3).

After adjustment for age, race, smoking status, and BMI, we identified associations between $\mathrm{Pb}$ and the levels of urine biomarkers UNTX-I and UCTX-II, biomarkers primarily reflective of turnover of mineralized tissues. A 5-unit increase in blood $\mathrm{Pb}$ level was associated with a $45 \%$ increase in uNTX-I and a $28 \%$ increase in uCTX-II levels (Table 4). These positive associations were unchanged before and after adjustment, and the results were stable when limited to postmenopausal women and further adjusted for HRT use (data not shown).

Significant interactions between age and $\mathrm{Pb}$ were identified for $\mathrm{C} 2 \mathrm{C}$ among women $(\mathrm{p}$ interaction 0.07), indicating that age affects the $\mathrm{Pb}$ effect for this biomarker. For representative ages 55, 65, and 75, the expected fold changes in $\mathrm{C} 2 \mathrm{C}$ were $1.08,1.00$, and 
0.91 for each 5 -fold change in $\mathrm{Pb}$, respectively (Table 4). There were no significant associations between $\mathrm{Pb}$ and $\mathrm{COMP}, \mathrm{HA}, \mathrm{CPII}$, or the ratio [C2C:CPII], among the entire sample of women (Table 4), or in analyses limited to post-menopausal women or further adjusted for HRT use ( $p>0.1$ for all, data not shown).

\subsection{Men}

The sample consisted of 329 men, with demographic and clinical characteristics as shown in Table 1 . The mean age among the men was 65 years, with a mean BMI of $30 \mathrm{~kg} / \mathrm{m}^{2}$. Of this group, 37\% were African American, 23\% were current smokers, and nearly $40 \%$ had radiographic knee osteoarthritis. The median and range values for whole blood $\mathrm{Pb}$ and biomarkers are shown in Table 2.

The median $\mathrm{Pb}$ level was $2.2 \mu \mathrm{g} / \mathrm{dL}$ (range from 0.5-25.1 $\mu \mathrm{g} / \mathrm{dL}$ ). The mean $\mathrm{Pb}$ level (lntransformed for t-tests) was noted to be higher among African American compared to Caucasian men, and among current smokers compared to non-smokers. Mean levels of $\ln$ $\mathrm{C} 2 \mathrm{C}$ were higher among African American compared to Caucasian men, while ln uNTX-I was higher in Caucasian men; other markers did not differ by race. $\mathrm{Pb}$ levels were significantly positively correlated with uCTX-II, COMP, and the ratio [C2C:CPII], and negatively correlated with CPII levels, but not correlated with uNTX-I, C2C, or HA (Table $3)$. There were no race or age interactions identified for $\mathrm{Pb}$ and any of the biomarker outcomes among men.

After adjustment for age, race, smoking status, and BMI, the only significant association was a borderline one between $\mathrm{Pb}$ and COMP, such that for a 5-unit increase in blood $\mathrm{Pb}$, there was an 8\% increase in COMP level (1.08 [95\%CI: 1.00-1.18]). There were no significant associations among men between $\mathrm{Pb}$ and uNTX-I, uCTX-II, C2C, CPII, [C2C:CPII], or HA.

\section{Discussion}

In summary, in unadjusted analyses, significant correlations were seen between $\mathrm{Pb}$ level and levels of uNTX-I, uCTX-II, and COMP among women and levels of uCTX-II, COMP, CPII, and [C2C:CPII] among men. After adjustment, among women, we identified statistically significant positive associations between whole blood Pb level and urine NTX-I and CTX-II, markers of bone and calcified cartilage turnover, respectively. Among men, there was a statistically significant positive association between blood $\mathrm{Pb}$ and COMP after adjustment. Blood $\mathrm{Pb}$ was not significantly associated with serum $\mathrm{C} 2 \mathrm{C}, \mathrm{CPII}$, the ratio [C2C:CPII], or $\mathrm{HA}$, in adjusted analyses in men or women.

The positive association among women between blood $\mathrm{Pb}$ and $\mathrm{uCTX}$-II level in this analysis signifies a potential association between $\mathrm{Pb}$ exposure and joint tissue metabolism, although we cannot determine the direction of this effect from the present cross-sectional study. It is unclear whether this finding reflects a direct effect of $\mathrm{Pb}$ on cartilage, or an indirect effect mediated by adverse effects of $\mathrm{Pb}$ on bone. Urine CTX-II is a quantitative marker of radiographic osteoarthritis (Meulenbelt et al. 2006; Reijman et al. 2004), and may be a relatively specific biomarker of calcified cartilage turnover at the junction of cartilage and subchondral bone (Tomiya et al. 2008;Bay-Jensen et al. 2008). Given the reported propensity for accumulation of $\mathrm{Pb}$ at the tidemark, the area of transition between calcified and more metabolically active non-calcified cartilage (Zoeger et al. 2006), and the report that CTX-II is primarily derived from sites at or near the junction of cartilage and subchondral bone (Bay-Jensen et al. 2008), uCTX-II may be a specific biomarker for the joint tissue most affected by $\mathrm{Pb}$ toxicity. We have identified significant associations between 
blood $\mathrm{Pb}$ and uCTX-II among women in our cohort; confirmation of this finding in other populations will provide a better understanding of its potential implications.

The strongest association between $\mathrm{Pb}$ and a biomarker among women was for uNTX-I, a marker of bone turnover in osteoporosis (Scariano et al. 1998) and in osteoarthritis (Bettica et al. 2002). Consistent with prior studies of markers of bone turnover and blood $\mathrm{Pb}$ levels (Potula et al. 2005;Machida et al. 2009), uNTX-I was highly associated with blood Pb level in the current analysis. Despite known variations in uNTX-I by menopausal and hormone replacement status, there was no difference after adjustment for these factors in the current analysis, potentially due to small numbers of premenopausal women and of women on hormone replacement therapy. The observed association in the current analysis between elevated levels of uNTX-I and higher levels of blood $\mathrm{Pb}$ is likely related to increased release of $\mathrm{Pb}$ into blood from bone in this population of primarily post-menopausal women in a high bone turnover state, consistent with prior reports (Machida et al. 2009). Although we did not identify an association between uNTX-I and blood $\mathrm{Pb}$ in men, in a study of elderly men participating in the VA Normative aging study, there was evidence of increased blood $\mathrm{Pb}$ with increasing uNTX-I levels, although this was not the focus of the study (Nie et al. 2009). The men in that study were older (mean age 69 years) with a higher median blood $\mathrm{Pb}$ level $(5 \mu \mathrm{g} / \mathrm{dL})$ compared to the current analysis, which may at least partly explain this difference.

In contrast to the women, the only significant association among the men was between blood $\mathrm{Pb}$ and serum COMP. Serum COMP, one of the most studied and validated cartilage biomarkers in relation to osteoarthritis (Clark et al. 1999;Jordan et al. 2003; Sharif et al. 1995b), is not specific to cartilage, as it is also found in meniscus, tendon, and ligament (Garnero et al. 2000;Petersson et al. 1998). Among women, there was no significant association between serum COMP and blood $\mathrm{Pb}$ after adjustment, despite a significant Spearman correlation coefficient. Prior studies have shown gender differences in COMP (Jordan et al. 2003; Sharif et al. 1995b;Kumm et al. 2006), with generally higher levels among men.

No significant associations were identified between $\mathrm{Pb}$ and serum $\mathrm{CPII}$ (marker of collagen synthesis), serum $\mathrm{C} 2 \mathrm{C}$ (marker of cartilage degradation), or their ratio [C2C:CPII] in adjusted analyses, despite significant correlations between $\mathrm{Pb}$ level and $\mathrm{CPII}$ and [C2C:CPII] among men. There was a significant interaction between age and $\mathrm{C} 2 \mathrm{C}$ among women, but the association between $\mathrm{Pb}$ and serum $\mathrm{C} 2 \mathrm{C}$ was not significant in either age group. A lack of association between radiographic osteoarthritis and serum $\mathrm{C} 2 \mathrm{C}$ has been reported (Mazzuca et al. 2006; Cahue et al. 2007; Cibere et al. 2009), and may represent a lack of a detectable relationship between the effects of $\mathrm{Pb}$ on uncalcified cartilage degradation, as reflected by serum $\mathrm{C} 2 \mathrm{C}$. Therefore, urine $\mathrm{C} 2 \mathrm{C}$ is recommended for future studies, as unlike serum $\mathrm{C} 2 \mathrm{C}$ this biomarker has revealed alterations in cartilage collagen degradation with the onset of knee osteoarthritis (Cibere et al. 2009). The lack of association between $\mathrm{Pb}$ and the ratio [C2C:CPII], despite evidence in the literature that such marker ratios may provide additional information beyond that from individual markers in isolation (Cahue et al. 2007; Cibere et al. 2009), may be in part due to adjustment of the models for race (associated with $\mathrm{C} 2 \mathrm{C}$ ) and smoking (associated with CPII).

The lack of association between blood $\mathrm{Pb}$ and serum $\mathrm{HA}$, often considered a marker of synovial inflammation (Wells et al. 1992; Sharif et al. 1995a), among men or women, is not supportive of a $\mathrm{Pb}$ effect on synovium. Studies have shown an effect of $\mathrm{Pb}$ on cultured synovial cells, including decreased proliferation and protein synthesis, but only in an in vitro experiment using 10-fold higher concentrations of $\mathrm{Pb}$, so it is unclear how those findings relate to $\mathrm{Pb}$ level and serum $\mathrm{HA}$ as analyzed in the current study (Goldberg et al. 1983). 
There are some limitations to the current study. Whole blood $\mathrm{Pb}$ measurements were used as a biomarker for $\mathrm{Pb}$ exposure. Specialized $\mathrm{x}$-ray fluorescence techniques to assess bone $\mathrm{Pb}$ are considered the "gold standard" for measurement of $\mathrm{Pb}$ storage in bone, but this procedure is expensive and not widely available (Barbosa et al. 2005; Sakai 2000). Since blood $\mathrm{Pb}$ levels reflect recent exposure as well as mobilization of $\mathrm{Pb}$ from bone (Barbosa et al. 2005; Nie et al. 2009), and blood $\mathrm{Pb}$ has been associated with all-cause mortality, cardiovascular disease, and renal disease (Staessen et al. 1992; Jain et al. 2007; Martin et al. 2006; Schober et al. 2006;Weisskopf et al. 2009; Khalil et al. 2009), this measure of $\mathrm{Pb}$ was used as a readily available and economical alternative biomarker for $\mathrm{Pb}$ exposure (Barbosa et al. 2005;Sakai 2000). The current study is also limited due to its cross-sectional design, although the potential for future longitudinal studies of $\mathrm{Pb}$ in this population exist. Bone density measurements have been collected as part of the parent study but were not interpreted or analyzed at the time of this analysis. The strengths of this study include a population-based, biracial sample and the inclusion of multiple biomarkers representing turnover of different joint tissues.

\section{Conclusions}

In conclusion, this is the first study evaluating potential effects of low levels of whole blood $\mathrm{Pb}$ on multiple biomarkers of joint tissue metabolism. Whole blood $\mathrm{Pb}$ levels reflect systemic $\mathrm{Pb}$ from both current exposure and bone turnover causing release of stored $\mathrm{Pb}$. Our results suggest that systemic $\mathrm{Pb}$ is associated with bone turnover (uNTX-I), as well as mineralized (uCTX-II) among women, and non-mineralized (COMP) cartilage turnover among men, but as this is a cross-sectional analysis, we cannot determine whether cartilage turnover is an indicator, or consequence, of $\mathrm{Pb}$ release. The association between blood $\mathrm{Pb}$ level and cartilage-associated biomarkers, along with our recent cross-sectional analysis showing associations between blood $\mathrm{Pb}$ and radiographic knee osteoarthritis and knee symptoms (Nelson et al. 2011), suggests the possibility that $\mathrm{Pb}$ may play a role in the pathophysiology of osteoarthritis. Longitudinal studies including assessments of radiographic and symptomatic osteoarthritis, in conjunction with both blood and bone $\mathrm{Pb}$, would be valuable to further evaluate the potential effects of $\mathrm{Pb}$ on joint symptoms, onset and progression of this highly prevalent and often debilitating disease.

\section{Research Highlights}

- We assessed whole blood lead in conjunction with osteoarthritis biomarkers.

- In women, blood lead is associated with urine biomarkers of calcified cartilage and bone turnover,

- And in men with cartilage oligomeric matrix protein, a serum marker of joint tissue metabolism,

- Suggestive of a gender-specific effect of lead on joint tissues of potential relevance in osteoarthritis.

\section{Acknowledgments}

We wish to thank Kathleen Shergy for technical assistance with biomarker assays, as well as the Johnston County Osteoarthritis Project staff and participants, without whom this study would not have been possible.

This work was funded in part by:

Nelson/Chaudhary: John A. Hartford Center of Excellence in Geriatrics; NIH/NIAMS T-32 training grant AR-07416; Nelson: NIH Loan Repayment 1 L30 AR056604 
Kraus/Stabler: NIH/NIA Claude D. Pepper OAIC 2 P60 AG11268 and P30 AG028716; NIH/NIAMS U01 AR 050898

Jordan: NIEHS/UNC Center for Environmental Health and Susceptibility 5P30-ES010126;

Jordan/Renner: Centers for Disease Control and Prevention/Association of Schools of Public Health S043 and S3486; Jordan/Renner/Schwartz: NIH/NIAMS Multipurpose Arthritis and Musculoskeletal Diseases Center grant 5 P60 AR49465

Poole: Shriners Hospitals and Canadian Institutes of Health Research

The funding sources had no role in study design, collection, analysis and interpretation of data; in the writing of the report; or in the decision to submit the paper for publication.

\section{Abbreviations}

$\begin{array}{ll}\text { uNTX-I } & \text { urinary cross-linked N telopeptide of type I collagen } \\ \text { uCTX-II } & \text { urinary C-telopeptide fragments of type II collagen } \\ \text { COMP } & \text { cartilage oligomeric matrix protein } \\ \text { C2C } & \text { cleavage neoepitope of type II collagen } \\ \text { CPII } & \text { type II procollagen synthesis C-propeptide } \\ \text { [C2C:CPII] } & \text { ratio of C2C to CPII } \\ \text { HA } & \text { hyaluronic acid } \\ \text { Pb } & \text { lead }\end{array}$

\section{Reference List}

Barbosa F, Tanus-Santos JE, Gerlach RF, Parsons PJ. A critical review of biomarkers used for monitoring human exposure to lead: Advantages, limitations, and future needs. Environ Health Perspect. 2005; 113:1669-1674. [PubMed: 16330345]

Barry PS, Mossman DB. Lead concentrations in human tissues. Br J Ind Med. 1970; 27:339-351. [PubMed: 5488693]

Bay-Jensen AC, Andersen TL, Charni-Ben TN, Kristensen PW, Kjaersgaard-Andersen P, Sandell L, Garnero P, Delaisse JM. Biochemical markers of type II collagen breakdown and synthesis are positioned at specific sites in human osteoarthritic knee cartilage. Osteoarthritis Cartilage. 2008; 16:615-623. [PubMed: 17950629]

Berlin K, Gerhardsson L, Borjesson J, Lindh E, Lundstrom N, Schutz A, Skerfving S, Edling C. Lead intoxication caused by skeletal disease. Scand J Work Environ Health. 1995; 21:296-300. [PubMed: 8553006]

Bettica P, Cline G, Hart DJ, Meyer J, Spector TD. Evidence for increased bone resorption in patients with progressive knee osteoarthritis - Longitudinal results from the Chingford study. Arthritis Rheum. 2002; 46:3178-3184. [PubMed: 12483721]

Cahue S, Sharma L, Dunlop D, Ionescu M, Song J, Lobanok T, King L, Poole AR. The ratio of type II collagen breakdown to synthesis and its relationship with the progression of knee osteoarthritis. Osteoarthritis Cartilage. 2007; 15:819-823. [PubMed: 17344068]

Carmouche JJ, Puzas JE, Zhang XP, Tiyapatanaputi P, Cory-Slechta DA, Gelein R, Zuscik M, Rosier RN, Boyce BF, O'Keefe RJ, Schwarz EM. Lead exposure inhibits fracture healing and is associated with increased chondrogenesis, delay in cartilage mineralization, and a decrease in osteoprogenitor frequency. Environ Health Perspect. 2005; 113:749-755. [PubMed: 15929899]

Centers for Disease Control and Prevention (CDC). Adult blood lead epidemiology and surveillance-United States, 2005-2007. MMWR Morb Mortal Wkly Rep. 2009; 58:365-369. [PubMed: 19373197] 
Christgau S, Garnero P, Fledelius C, Moniz C, Ensig M, Gineyts E, Rosenquist C, Qvist P. Collagen type II C-telopeptide fragments as an index of cartilage degradation. Bone. 2001; 29:209-215. [PubMed: 11557363]

Chu Q, Lopez M, Hayashi K, Ionescu M, Billinghurst RC, Johnson KA, Poole AR, Markel MD. Elevation of a collagenase generated type II collagen neoepitope and proteoglycan epitopes in synovial fluid following induction of joint instability in the dog. Osteoarthritis Cartilage. 2002; 10:662-669. [PubMed: 12479389]

Cibere J, Zhang H, Garnero P, Poole AR, Lobanok T, Saxne T, Kraus VB, Way A, Thorne A, Wong H, Singer J, Kopec J, Guermazi A, Peterfy C, Nicolaou S, Munk PL, Esdaile JM. Association of biomarkers with pre-radiographically defined and radiographically defined knee osteoarthritis in a population-based study. Arthritis Rheum. 2009; 60:1372-1380. [PubMed: 19404937]

Clark AG, Jordan JM, Vilim V, Renner JB, Dragomir AD, Luta G, Kraus VB. Serum cartilage oligomeric matrix protein reflects osteoarthritis presence and severity: the Johnston County Osteoarthritis Project. Arthritis Rheum. 1999; 42:2356-2364. [PubMed: 10555031]

Dowd TL, Rosen JF, Mints L, Gundberg CM. The effect of $\mathrm{Pb}(2+)$ on the structure and hydroxyapatite binding properties of osteocalcin. Biochim Biophys Acta. 2001; 1535:153-163. [PubMed: 11342004]

Elliot A, Kraus VB, Luta G, Stabler T, Renner JB, Woodard J, Dragomir A, Helmick C, Hochberg M, Jordan JM. Serum hyaluronan levels and radiographic knee and hip osteoarthritis in AfricanAmericans and Caucasians in the Johnston County Osteoarthritis Project. Arthritis \& Rheumatism. 2005; 52:105-111. [PubMed: 15641044]

Fullmer CS. Lead-Calcim Interactions: Involvement of 1,25-Dihydroxyvitamin D. Environ Res. 1997; 72:45-55. [PubMed: 9012371]

Garnero P, Rousseau J, Delmas PD. Molecular basis and clinical use of biochemical markers of bone, cartilage, and synovium in joint diseases. Arthritis Rheum. 2000; 43:953. [PubMed: 10817547]

Georges C, Vigneron H, Ayral X, Listrat V, Ravaud P, Dougados M, Sharif M, Dieppe P, Saxne T. Serum biologic markers as predictors of disease progression in osteoarthritis of the knee. Arthritis Rheum. 1997; 40:590-591. [PubMed: 9082954]

Goldberg RL, Kaplan SR, Fuller GC. Effect of heavy metals on human rheumatoid synovial cell proliferation and collagen synthesis. Biochem Pharmacol 1983. 1983 Sep 15.32:2763-2766.

Jain NB, Potula V, Schwartz J, Vokonas PS, Sparrow D, Wright RO, Nie H, Hu H. Lead levels and ischemic heart disease in a prospective study of middle-aged and elderly men: the VA Normative Aging Study. Environ Health Perspect. 2007; 115:871-875. [PubMed: 17589593]

Jordan JM, Helmick CG, Renner JB, Luta G, Dragomir AD, Woodard J, Fang F, Schwartz TA, Abbate LM, Callahan LF, Kalsbeek WD, Hochberg MC. Prevalence of knee symptoms and radiographic and symptomatic knee osteoarthritis in African Americans and Caucasians: The Johnston County Osteoarthritis Project. J Rheumatol. 2007; 34:172-180. [PubMed: 17216685]

Jordan JM, Luta G, Stabler T, Renner JB, Dragomir AD, Vilim V, Hochberg MC, Helmick CG, Kraus VB. Ethnic and sex differences in serum levels of cartilage oligomeric matrix protein: the Johnston County Osteoarthritis Project. Arthritis Rheum. 2003; 48:675-681. [PubMed: 12632420]

Khalil N, Wilson JW, Talbott EO, Morrow LA, Hochberg MC, Hillier TA, Muldoon SB, Cummings SR, Cauley JA. Association of blood lead concentrations with mortality in older women: a prospective cohort study. Environ Health. 2009; 8:15. [PubMed: 19344498]

Kojima T, Kojima M, Noda K, Ishiguro N, Poole AR. Influences of menopause, aging, and gender on the cleavage of type II collagen in cartilage in relationship to bone turnover. Menopause. 2008; 15:133-137. [PubMed: 18257147]

Kong SY, Stabler TV, Criscione LG, Elliott AL, Jordan JM, Kraus VB. Diurnal variation of serum and urine biomarkers in patients with radiographic knee osteoarthritis. Arthritis Rheum. 2006; 54:2496-2504. [PubMed: 16868970]

Kraus VB, Kepler TB, Stabler TV, Renner JB, Atif U, Jordan JM. First qualification study of serum biomarkers as indicators of total body burden of osteoarthritis. PLoS Medicine Under review. 2009 Ref Type: Generic. 
Kumm J, Tamm A, Veske K, Lintrop M, Tamm A. Associations between cartilage oligomeric matrix protein and several articular tissues in early knee joint osteoarthritis. Rheumatology (Oxford). 2006; 45:1308-1309. [PubMed: 16920749]

Kutner, M.; Nachtsheim, C.; Neter, J.; Li, W. Applied Linear Statistical Models. Irwin: McGraw-Hill; 2004.

Machida M, Sun SJ, Oguma E, Kayama F. High bone matrix turnover predicts blood levels of lead among perimenopausal women. Environ Res. 2009; 109:880-886. [PubMed: 19595303]

Martin D, Glass TA, Bandeen-Roche K, Todd AC, Shi W, Schwartz BS. Association of blood lead and tibia lead with blood pressure and hypertension in a community sample of older adults. Am $\mathrm{J}$ Epidemiol. 2006; 163:467-478. [PubMed: 16421242]

Matyas JR, Atley L, Ionescu M, Eyre DR, Poole AR. Analysis of cartilage biomarkers in the early phases of canine experimental osteoarthritis. Arthritis Rheum. 2004; 50:543-552. [PubMed: 14872497]

Mazzuca SA, Poole AR, Brandt KD, Katz BP, Lane KA, Lobanok T. Associations between joint space narrowing and molecular markers of collagen and proteoglycan turnover in patients with knee osteoarthritis. J Rheumatol. 2006; 33:1147-1151. [PubMed: 16652436]

Meulenbelt I, Kloppenburg M, Kroon HM, Houwing-Duistermaat JJ, Garnero P, Hellio le Graverand MP, DeGroot J, Slagboom PE. Urinary CTX-II levels are associated with radiographic subtypes of osteoarthritis in hip, knee, hand, and facet joints in subject with familial osteoarthritis at multiple sites: the GARP study. Ann Rheum Dis. 2006; 65:360-365. [PubMed: 16079167]

Mouritzen U, Christgau S, Lehmann HJ, Tanko LB, Christiansen C. Cartilage turnover assessed with a newly developed assay measuring collagen type II degradation products: influence of age, sex, menopause, hormone replacement therapy, and body mass index. Ann Rheum Dis. 2003; 62:332336. [PubMed: 12634232]

Muntner P, Menke A, DeSalvo KB, Rabito FA, Batuman V. Continued decline in blood lead levels among adults in the United States: the National Health and Nutrition Examination Surveys. Arch Intern Med. 2005; 165:2155-2161. [PubMed: 16217007]

Mushak P. New Directions in the Toxicokinetics of Human Lead Exposure. Neurotoxicology. 1993; 14:29-42. [PubMed: 8247403]

Nash D, Magder LS, Sherwin R, Rubin RJ, Silbergeld EK. Bone density-related predictors of blood lead level among peri- and postmenopausal women in the United States: The Third National Health and Nutrition Examination Survey, 1988-1994. Am J Epidemiol. 2004; 160:901-911. [PubMed: 15496543]

Nelson AE, Shi XA, Schwartz TA, Chen JC, Renner JB, Caldwell KL, Helmick CG, Jordan JM. Whole blood lead levels are associated with radiographic and symptomatic knee osteoarthritis: a cross-sectional analysis in the Johnston County Osteoarthritis Project. Arthritis Res Ther. 2011; 13:R37. [PubMed: 21362189]

Nelson F, Dahlberg L, Laverty S, Reiner A, Pidoux I, Ionescu M, Fraser GL, Brooks E, Tanzer M, Rosenberg LC, Dieppe P, Poole AR. Evidence for altered synthesis of type II collagen in patients with osteoarthritis. J Clin Invest. 1998; 102:2115-2125. [PubMed: 9854047]

Nie H, Sanchez BN, Wilker E, Weisskopf MG, Schwartz J, Sparrow D, Hu H. Bone lead and endogenous exposure in an environmentally exposed elderly population: the normative aging study. J Occup Environ Med. 2009; 51:848-857. [PubMed: 19528829]

Osterloh JD, Kosnett MJ, Becker CE, Osterloh J, Kelly TJ, Pasta DJ. Factors Influencing Bone Lead Concentration in a Suburban Community Assessed by Noninvasixe K X-ray Fluorescence. JAMA. 1994; 271:197-203. [PubMed: 8277545]

Petersson IF, Boegard T, Svensson B, Heinegard D, Saxne T. Changes in cartilage and bone metabolism identified by serum markers in early osteoarthritis of the knee joint. Br J Rheumatol. 1998; 37:46-50. [PubMed: 9487250]

Potula V, Henderson A, Kaye W. Calcitropic hormones, bone turnover, and lead exposure among female smelter workers. Arch Environ Occup Health. 2005; 60:195-204. [PubMed: 17214290]

Pounds JG, Long GJ, Rosen JF. Cellular and molecular toxicity of lead in bone. Environ Health Perspect 1991. 1991 Feb.91:17-32. [Review] [144 refs]. 
Reijman M, Hazes JMW, Bierma-Zeinstra SMA, Koes BW, Christgau S, Christiansen C, Uitterlinden AG, Pols HAP. A new marker for osteoarthritis - Cross-sectional and longitudinal approach. Arthritis Rheum. 2004; 50:2471-2478. [PubMed: 15334460]

Sakai T. Biomarkers of lead exposure. Ind Health. 2000; 38:127-142. [Review] [141 refs]. [PubMed: 10812836]

Scariano JK, Glew RH, Bou-Serhal CE, Clemens JD, Garry PJ, Baumgartner RN. Serum levels of cross-linked N-telopeptides and aminoterminal propeptides of type I collagen indicate low bone mineral density in elderly women. Bone. 1998; 23:471-477. [PubMed: 9823455]

Schober SE, Mirel LB, Graubard BI, Brody DJ, Flegal KM. Blood lead levels and death from all causes, cardiovascular disease, and cancer: results from the NHANES III mortality study. Environ Health Perspect. 2006; 114:1538-1541. [PubMed: 17035139]

Sharif M, George E, Shepstone L, Knudson W, Thonar MA, Thonar EJ, Cushnaghan J, Dieppe P. Serum hyaluronic acid level as a predictor of disease progression in osteoarthritis of the knee. Arthritis Rheum. 1995a; 38:760-767. [PubMed: 7779118]

Sharif M, Saxne T, Shepstone L, Kirwan JR, Elson CJ, Heinegard D, Dieppe PA. Relationship between serum cartilage oligomeric matrix protein levels and disease progression in osteoarthritis of the knee joint. Br J Rheumatol. 1995b; 34:306-310. [PubMed: 7788143]

Staessen JA, Lauwerys RR, Buchet J, Bulpitt CJ, Rondia D, Vanrenterghem Y, Amery A. Impairment of renal function with increasing blood lead concentrations in the general population. $\mathrm{N}$ Engl $\mathrm{J}$ Med. 1992; 327:151-156. [PubMed: 1608406]

Subramanian KS. Storage and preservation of blood and urine for trace element analysis. Biol Trace Elem Res. 1995; 49:187-210. A review. [PubMed: 8562287]

Symanski E, Hertz-Picciotto I. Blood lead levels in relation to menopause, smoking, and pregnancy history. Am J Epidemiol. 1995; 141:1047-1058. [PubMed: 7771441]

Tomiya M, Fujikawa K, Ichimura S, Kikuchi T, Yoshihara Y, Nemoto K. Skeletal unloading induces a full-thickness patellar cartilage defect with increase of urinary collagen II CTx degradation marker in growing rats. Bone. 2008; 44:295-305. [PubMed: 19000792]

Tsaih SW, Korrick S, Schwartz J, Lee ML, Amarasiriwardena C, Aro A, Sparrow D, Hu H. Influence of bone resorption on the mobilization of lead from bone among middle-aged and elderly men: the Normative Aging Study. Environ Health Perspect. 2001; 109:995-999. [PubMed: 11675263]

Vilim V, Voburka Z, Vytasek R, Senolt L, Tchetverikov I, Kraus VB, Pavelka K. Monoclonal antibodies to human cartilage oligomeric matrix protein (COMP): epitope mapping and characterization of sandwich ELISA. Cinica Chimica Acta. 2002; 328:59-69.

Wang ST, Peter F. The stability of human blood lead in storage. J Anal Toxicol. 1985; 9:85-88. [PubMed: 3921764]

Weisskopf MG, Jain N, Nie H, Sparrow D, Vokonas P, Schwartz J, Hu H. A prospective study of bone lead concentration and death from all causes, cardiovascular diseases, and cancer in the Department of Veterans Affairs Normative Aging Study. Circulation. 2009; 120:1056-1064. [PubMed: 19738141]

Wells AF, Klareskog L, Lindblad S, Laurent TC. Correlation between increased hyaluronan localized in arthritic synovium and the presence of proliferating cells. A role for macrophage-derived factors. Arthritis Rheum. 1992; 35:391-396. [PubMed: 1567487]

Wittmers LE Jr, Aufderheide AC, Wallgren J, Rapp G Jr, Alich A. Lead in bone. IV. Distribution of lead in the human skeleton. Arch Environ Health. 1988; 43:381-391. [PubMed: 3196073]

Zoeger N, Roschger P, Hofstaetter JG, Jokubonis C, Pepponi G, Falkenberg G, Fratzl P, Berzlanovich A, Osterode W, Streli C, Wobrauschek P. Lead accumulation in tidemark of articular cartilage. Osteoarthritis Cartilage. 2006; 14:906-913. [PubMed: 16678451]

Zuscik MJ, Puzas E, O'Keefe RJ, Sheu T, Holz JD, Rosier RN, Ubayawardena R. Pb exposure regulates a complex interplay of signaling pathways in articular chondrocytes that ultimately leads to phenotypic changes resembling osteoarthritis. The Toxicologist CD-An official Journal of the Society of Toxicology 90[S-1]. 2006 


\section{Table 1}

Characteristics of the biomarkers and metals exposure sub-study of the Johnston County Osteoarthritis Project

\begin{tabular}{lrrr}
\hline Clinical Characteristics & Women $(\mathbf{n}=342)$ & $\begin{array}{r}\text { Men }(\mathbf{n}=329) \\
\text { Mean }(\mathbf{S D}) \text { or \% }\end{array}$ & $\begin{array}{r}\text { Mean }(\mathbf{S D}) \text { or \% } \\
\text { Overall }(\mathbf{n = 1 6 3 5})^{*}\end{array}$ \\
\hline Mean age (SD, years) & $62.4(9.4)$ & $64.5(10.8)$ & $65.3(11.0)$ \\
Mean BMI (SD, in $\left.\mathbf{~ k g} / \mathbf{m}^{\mathbf{2}}\right)$ & $30.8(7.0)$ & $29.8(5.4)$ & $31.2(7.1)$ \\
African American $(\%)$ & 35.1 & 37.4 & 35.6 \\
Current smoker $(\%)$ & 17.7 & 23.1 & 16.5 \\
Knee Osteoarthritis $(\%) \dagger$ & 32.8 & 38.9 & 40.3 \\
\hline
\end{tabular}

SD: standard deviation; BMI: Body Mass Index

* Overall numbers are for the entire sample with blood $\mathrm{Pb}$ and knee radiographs, including the biomarker subset.

${ }^{\dagger}$ Knee osteoarthritis defined as a Kellgren-Lawrence grade $\geq 2$ at either knee or knee replacement due to osteoarthritis. 


\section{Table 2}

Whole blood lead and serum or urine biomarker levels in the biomarkers and metals exposure sub-study of the Johnston County Osteoarthritis Project, by gender

\begin{tabular}{lrrrr}
\hline Concentration & \multicolumn{2}{c}{ Women $(\mathbf{n = 3 4 2})^{\boldsymbol{a}}$} & \multicolumn{2}{c}{ Men $(\mathbf{n = 3 2 9})$} \\
& Median & Range & Median & Range \\
\hline Whole blood Lead $(\mu \mathrm{g} / \mathrm{dL})$ & 1.9 & $0.5-25.4$ & 2.2 & $0.5-25.1$ \\
uNTX-I $(\mathrm{nmol}$ BCE/mmol creatinine) & 86.5 & $12.8-996.4$ & 39.5 & $5.9-4214.7$ \\
uCTX-II $(\mathrm{ng} / \mathrm{mmol}$ creatinine) & 185.2 & $8.09-1396.6$ & 234.5 & $47.5-2705.0$ \\
COMP $(\mathrm{ng} / \mathrm{mL})$ & 1597.0 & $472.9-4429.6$ & 1329.0 & $339.3-7279.0$ \\
C2C $(\mathrm{ng} / \mathrm{mL})$ & 167.7 & $72.0-1060.2$ & 177.1 & $54.0-935.6$ \\
CP II $(\mathrm{ng} / \mathrm{mL})$ & 857.6 & $228.0-2991.3$ & 937.8 & $319.9-2352.1$ \\
{$[$ C2C:CPII $]$ ratio } & 0.20 & $0.05-0.76$ & 0.19 & $0.05-0.92$ \\
HA $(\mathrm{ng} / \mathrm{mL})$ & 12.5 & $0.1-391.3$ & 40.8 & $0.6-707.8$ \\
\hline
\end{tabular}

$a_{3 \text { missing serum and } 12 \text { missing urine data }}$

uCTX-II- Urine C-telopeptide fragments of type II collagen, COMP-Cartilage Oligomeric matrix protein, CPII: type II collagen carboxypropeptide, C2C: cleavage neoepitope of type II collagen, HA- Hyaluronic Acid, uNTX-I- urine N-telopeptide of type I collagen, BCE: bone collagen equivalent 


\section{Table 3}

Spearman correlation coefficients (unadjusted) between individual biomarkers and blood $\mathrm{Pb}$ in the biomarkers and metals exposure sub-study of the Johnston County Osteoarthritis Project

\begin{tabular}{lcccc}
\hline & \multicolumn{2}{c}{ Women } & \multicolumn{2}{c}{ Men } \\
Biomarker & $\begin{array}{c}\text { Spearman } \\
\text { coefficient }\end{array}$ & $\mathbf{9 5 \%}$ CI & $\begin{array}{c}\text { Spearman } \\
\text { coefficient }\end{array}$ & 95\% CI \\
\hline uNTX-I & $\mathbf{0 . 2 2 0}$ & $\mathbf{0 . 1 0 7 , 0 . 3 1 4}$ & 0.005 & $-0.103,0.113$ \\
uCTX-II & $\mathbf{0 . 2 0 2}$ & $\mathbf{0 . 0 9 3 , 0 . 3 0 0}$ & $\mathbf{0 . 1 1 3}$ & $\mathbf{0 . 0 0 4 , 0 . 2 1 8}$ \\
COMP & $\mathbf{0 . 1 3 8}$ & $\mathbf{0 . 0 1 6 , 0 . 2 2 6}$ & $\mathbf{0 . 2 3 1}$ & $\mathbf{0 . 1 2 5 , 0 . 3 3 0}$ \\
C2C & -0.013 & $-0.120,0.093$ & 0.038 & $-0.070,0.146$ \\
CPII & 0.028 & $-0.079,0.134$ & -0.110 & $-0.215,-0.002$ \\
[C2C:CPII] & -0.026 & $-0.132,0.081$ & $\mathbf{0 . 1 4 4}$ & $\mathbf{0 . 0 3 7 , 0 . 2 4 8}$ \\
HA & 0.067 & $-0.039,0.172$ & -0.003 & $-0.110,0.106$ \\
\hline
\end{tabular}

uNTX-I- urine N-telopeptide of type I collagen, uCTX-II- Urine C-telopeptide fragments of type II collagen, COMP-Cartilage oligomeric matrix protein, HA- Hyaluronic Acid, C2C: cleavage neoepitope of type II collagen, CPII: type II collagen carboxy-propeptide 


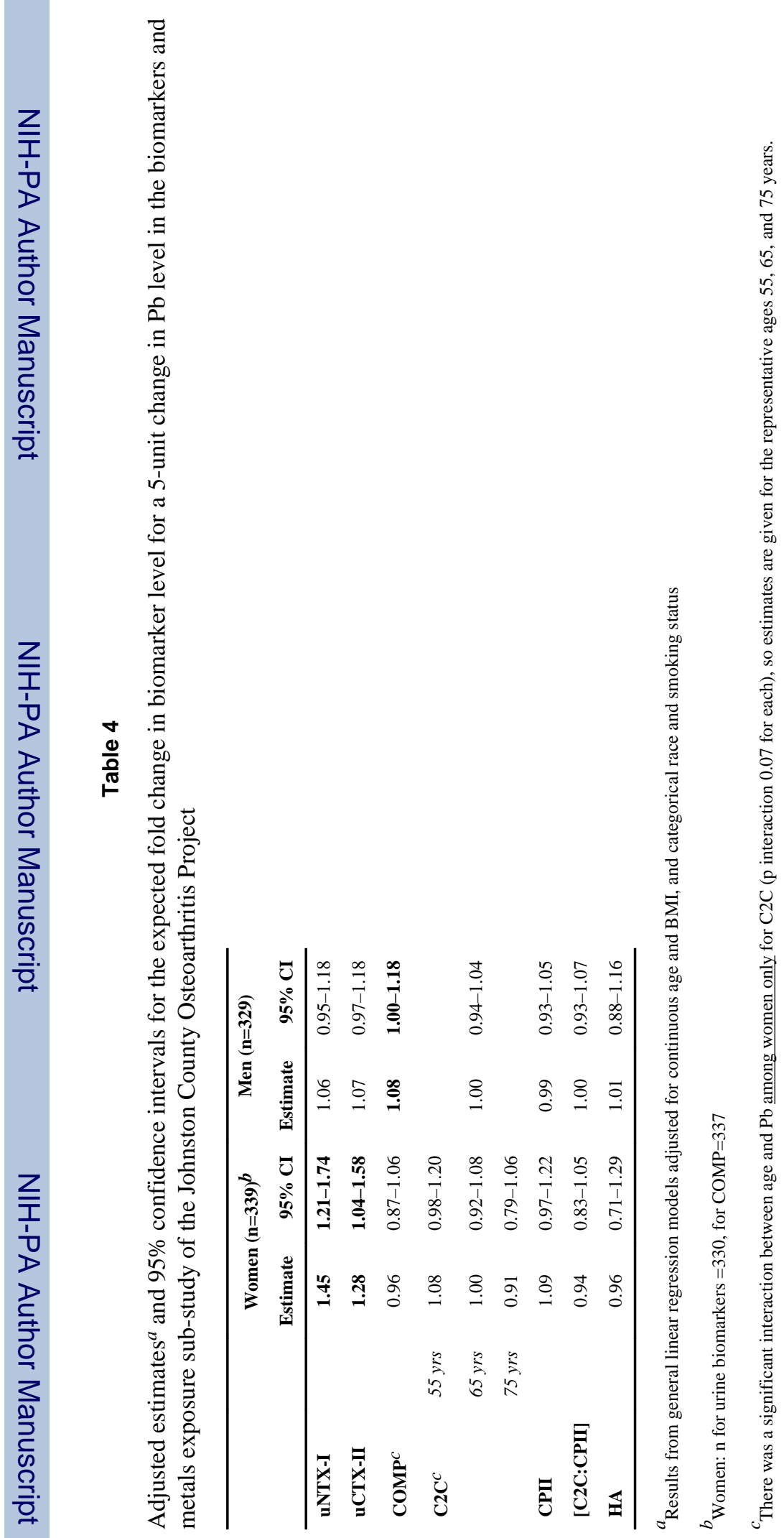

